\title{
A Estrutura Conceitual da Experiência: McDowell e o debate Kant-Hegel
}

\author{
The Conceptual Structure of Experience: \\ McDowell and the Kant-Hegel Debate
}

* Erick Lima

\begin{abstract}
Resumo: O presente artigo pretende considerar a interpretação proposta por McDowell acerca do debate epistemológico travado entre Kant e Hegel. O fio condutor que adoto concerne à estrutura conceitual da experiência. Primeiramente, tento elucidar o sentido mais geral da recuperação de estratégias hegelianas pela filosofia analítica (1). Em segundo lugar, procuro descrever a posição mais geral adotada por McDowell à luz do debate Kant-Hegel (2.1 e 2.2), seu apelo ao argumento wittgensteiniano da linguagem privada (2.3) e sua inserção no debate moderno em torno da percepção de qualidades secundárias e de cores (2.4). Em seguida, eu tento a interpretação de alguns argumentos na Fenomenologia do Espírito seguindo indicações de McDowell (3). Finalmente, baseando-me na obra Having the World in View, procuro mostrar o sentido geral de sua interpretação alegórica da dialética do senhor e do escravo (4).
\end{abstract}

Palavras-chave: Kant. Hegel. McDowell. Percepção. Experiência. Contextualismo.

\begin{abstract}
This paper aims at considering McDowell's interpretation of the epistemological debate between Kant and Hegel. The main issue to be discussed here concerns the conceptual structure of experience. Firstly, I intend to elucidate the meaning of Hegelian strategies for issues in the analytical tradition (1). Secondly, I attempt to delineate McDowell's most general position in light of the Kant-Hegel debate (2.1 e 2.2), as well as his appeal to Wittgenstein's "private language argument" (2.3) and his intervention in the modern discussion on the perception of secondary qualities and colors (2.4). Then, I try to interpret some developments in the Phenomenology of Spirit following
\end{abstract}

* Professor Adjunto no Departamento de Filosofia da Universidade de Brasília. Professor do Programa de Pós-graduação em Filosofia da Universidade de Brasília (PPGFIL-UnB). <callima_er@hotmail.com> 
McDowell's indications (3). Finally, I intend to point out the meaning of McDowell's "allegorical" interpretation of Hegel's discussion about Lordship and Bondage in Having the World in View(4).

Keywords: Kant. Hegel. McDowell. Perception. Experience. Contextualism.

\section{Hegel e a Filosofia Analítica: notas}

Se pudéssemos resumir num único ponto aquilo que tem se tornado importante em Hegel para a epistemologia analítica seriam aquelas tendências que encorajam à tematização do contextualismo e do holismo semântico ${ }^{1}$. Parece, então, que Hegel antecipa, nas peculiaridades de seu esforço filosófico, a radicalização wittgensteiniana do assim chamado princípio fregeano do contexto, antecipado por sua vez pela teoria kantiana dos juízos ${ }^{2}$. Brandom entende, em geral, o holismo de Hegel como sendo uma posição epistemológica que rejeita o atomismo semântico por sustentar que a imediatidade pressupõe determinidade de conteúdo, articulação do conteúdo determinado por relações de incompatibilidade material, o que significa, por sua vez, a ideia de que a "imediatidade somente pode ser feita inteligível frente ao pano de fundo de relações mediadoras de exclusão"3.

John McDowell promove uma discussão em torno do conteúdo nãoconceitual da experiência perceptiva, discussão que se processa no sentido de superar uma ainda supostamente persistente diferenciação kantiana ${ }^{4}$ entre conceito e intuição ${ }^{5}$, afastando as aporias do representacionalismo atomista ${ }^{6}$. Tal como eu vejo o desenvolvimento teórico de McDowell, ele pertence a uma tendência filosófica na qual se tornou estratégico explorar o contextualismo. Ainda antes que a tradição analítica tivesse assumido posições atomistas e construtivistas, com a ideia de Russell de um conhecimento por acquaintance como a base do criticismo analítico das descrições, a lógica funcionalista de Frege já tinha proposto uma relação entre conceito e argumento que se contrapunha à relação, sustentada por Aristóteles, entre a substância individual e seus acidentes.

\footnotetext{
Ver BRANDOM, 2011.

REDDING, 2007, 9.

BRANDOM, 2002, 182/183.

KANT, 1968, III, 74.

"As capacidades conceitualmente relevantes são inseridas na receptividade ... Não é que elas sejam exercidas num fornecimento extra-conceitual da receptividade. Nós deveríamos entender aquilo que Kant denomina "intuição" - insumo experimental - não como um mero acolhimento do dado extra-conceitual, mas como um tipo de ocorrência ou estado que já tem algum conteúdo conceitual" (McDOWELL, 1994, 9).

6 BRANDOM, 1994, 93.
} 
No Tractatus, Wittgenstein ilustra esta concepção de uma relação mais inerente usando sua definição peculiar da independência do objeto, a qual é talvez a mais importante ideia da ontologia que ele desenvolve como correspondente a sua teoria pictórica da proposição. "A coisa é independente (selbständig) na medida em que pode ocorrer em todas as situações possíveis, mas esta forma de independência (Selbständigkeit) é uma forma de conexão com o estado-de-coisas, uma forma de dependência (Unselbständigkeit)" ".

De acordo com esta concepção paradoxal de autossuficiência do objeto, nós temos de considerar todos os estados-de-coisa, nos quais um objeto pode desempenhar o papel de conceito ou de argumento, como constitutivos da essência dos objetos. "Objetos contêm a possibilidade de todas as situações"8. "A possibilidade de sua ocorrência em estadosde-coisa é a forma de um objeto" 9 . Esta posição é a base para uma compreensão contextualista da proposição ${ }^{10}$ : a ideia de que o sentido de algo é determinado apenas no contexto da proposição. "Somente proposições tem sentido; somente no contexto da proposição um nome tem significado"11.

\section{Hegel como uma alternativa}

Seguindo a teoria kantiana da experiência, mas não seu idealismo transcendental, Hegel pretende considerar, sobretudo na Fenomenologia, tudo que pertence ao mundo humano - tudo o que, experienciado

2.0122, WITTGENSTEIN, 1984, 1, 12.

2.014, WITTGENSTEIN, 1984, 1, 12.

2.0141, WITTGENSTEIN, 1984, 1, 12.

10 Uma enunciação típica da maneira pela qual o Wittgenstein dos anos trinta começa a radicalizar este princípio no sentido de um holismo semântico - e que se consuma nas Investigações Filosóficas - aparece no Livro Azul: "o signo (a sentença) obtém seu significado a partir de um sistema de signos, a partir da linguagem à qual ele pertence. Em suma: compreender uma sentença significa compreender uma linguagem. Enquanto parte de um sistema de linguagem, pode-se dizer, uma sentença tem vida." (WITTGENSTEIN, 1984, 5, 21). É digno de nota que Wittgenstein faça, no Livro Azul, uma das primeiras enunciações da noção de "jogos de linguagem". Justamente esta noção nos permite entender Wittgenstein comprometido, a partir dos anos trinta, com a radicalização holista do contextualismo, uma vez que na tese do "significado como uso", também enunciada no Livro Azul, o significado de termos e o sentido de proposições somente são apreensíveis em geral no contexto das práticas sociais e nos jogos de linguagem onde os nomes e expressões são empregados. Brandom entende, em geral, o holismo de Hegel como sendo uma posição epistemológica que rejeita o atomismo semântico por sustentar que a imediatidade pressupõe determinidade de conteúdo, articulação do conteúdo determinado por relações de incompatibilidade material, o que significa, por sua vez, a ideia de que a "imediatidade somente pode ser feita inteligível frente ao pano de fundo de relações mediadoras de exclusão." (BRANDOM, 2002, 182-183).

11 3.3, WITTGENSTEIN, 1984, 1, 20. 
imanentemente, depende da interação entre mente e mundo - em termos da mediação recíproca entre sujeito e objeto. Esta interação pode apenas ser percebida se nós já tivermos criticado e dissolvido o mito do dado, a tese de um "abismo entre sujeito e objeto" ${ }^{12}$, a ideia de uma dimensão objetiva que está completamente além dos conteúdos pensáveis e, portanto, fora do alcance da prática humana ou da Vermittlung überhaupt ${ }^{13}$.

$\mathrm{Eu}$ creio que McDowell sublinhe o mesmo viés, ainda que com uma ênfase epistemológica em nossa interação com o mundo, quando ele sustenta que o dado não deva ser defendido simplesmente por "fobia do idealismo", a fim de que não percamos a independência da realidade. "O constrangimento vem de fora do pensamento, mas não de fora do que é pensável. Quando nós traçamos justificações retrospectivamente, a última coisa que alcançamos é ainda um conteúdo pensável, não algo mais anterior do que um mero apontar para uma porção do dado ... os conteúdos pensáveis que são últimos na ordem da justificação são conteúdos da experiência, e participando da experiência uma pessoa está aberta a fatos manifestos, fatos que obtém de qualquer maneira e que se imprimem na sua sensibilidade"14.

O apelo à segunda natureza como instância protoconceitual é o que faz de Hegel, de acordo com McDowell, um pensador focado na interação, particularmente na interação entre mente e mundo. Tal como McDowell sugere implicitamente, isso também permite a compatibilidade do idealismo de Hegel com um empirismo mínimo e uma concepção aberta, falibilista, da experiência como interação e cooperação entre espontaneidade e receptividade ${ }^{15}$. Penso ser admirável que Hegel conceba ambas as formas mínimas de interação com o mundo, a teórica e a prática, certeza sensível e desejo, como formas ainda confusas de meras mediações. Isto nos conduz diretamente à ideia de McDowell de um intelecto engajado e pode ajudar a esclarecer porque a sua interpretação de Hegel em Having the World in View é radicalizada em termos de uma consideração alegórica ${ }^{16}$ da discussão sobre "Senhorio e Escravidão", a

12 "Assim, Kant põe a atividade aperceptiva espontânea no centro de sua figura da pretensão de objetividade da consciência sensorial. A livre atividade de conduzir as cognições à unidade da apercepção é um precursor, em Kant, para aquilo que figura em Hegel como o livre auto-desenvolvimento do conceito - um arranjo no qual a ideia do direcionamento do pensamento para objetos não mais inclui nada que pudesse parecer com um abismo entre sujeito e objeto." (McDOWELL, 2009, 148).

13 HEGEL, 1970, 7, 114-115.

14 McDOWELL, 1994, 28.

15 McDOWELL, 1994, XX.

16 McDOWELL, 2009, 163. 
qual sustenta uma relação inerente, primeiramente biológica ${ }^{17}$, entre o si empírico e a consciência aperceptiva.

\subsection{O dilema percebido na epistemologia contemporânea}

Segundo McDowell, a filosofia analítica, sobretudo em seus esforços epistemológicos, esteve subserviente a uma inextirpável oscilação entre duas posturas radicalmente opostas e, em certa medida, em si mesmas insustentáveis ${ }^{18}$. McDowell discute tais posições principalmente a partir de Wilfrid Sellars, Bertrand Russell e Donald Davidson, personagens importantíssimos nas discussões epistemológicas no ambiente analítico, profundamente inspiradores para McDowell, num teor cuja discussão precisa eu infelizmente terei de relegar a outra ocasião. A primeira posição seria aquela que teria sofrido o duro ataque de Sellars em "Empirismo e Filosofia da Mente", em 1956. Trata-se da posição fundacionalista, fortemente inspirada pelo empirismo clássico, a qual encontrou acolhida, já no ambiente analítico de discussão, em Moore e na forma como Russell defende, interessado em respaldar sua compreensão de conhecimento por acquaintance e a concepção de análise lógica da linguagem, o atomismo lógico. Trata-se da posição que procura basear o conhecimento empírico em dados brutos, acolhidos passivamente a partir da experiência perceptiva.

A outra posição, consagrada principalmente pela crítica de Sellars ao atomismo e ao empirismo, rejeita o dado bruto como um mito e sustenta o caráter conceitual da experiência perceptiva, sobretudo do ponto de vista da justificação de suas pretensões de validade, ou seja, procura não compreender o conhecimento empírico fora da dimensão discursiva em que ele justifica suas pretensões cognitivas.

Se tivéssemos de traçar uma predileção por parte de McDowell, seria sem dúvida por essa última vertente, a qual critica veementemente a tentativa do empirismo de justificar conhecimentos empíricos através da capacidade perceptiva de retenção dos dados, os quais são considerados, muitas vezes, como passíveis de serem acessados imediatamente. "Esta relação entre mente e mundo é normativa, logo, nesse sentido, o pensar que aponta para o juízo, ou seja, para a fixação da crença, é capaz de responder ao mundo - a como as coisas são - seja ele corretamente executado ou não" ${ }^{19}$. O grande problema dessa vertente

\footnotetext{
17 McDOWELL, 2009, 161.

18 "Uma tendência a oscilar entre um par de posições insatisfatórias: de um lado, um coerencialismo que ameaça desconectar o pensamento da realidade, e de outro lado, um vão apelo ao dado, no sentido de meras presenças que se supõem constituírem os últimos fundamentos para os juízos empíricos." (McDOWELL, 1994, 24).

19 McDOWELL, 1994, XII.
} 
seria, para McDowell, assim como para Sellars, a intenção de justificar juízos, inferências, proposições e conhecimentos em uma instância nãoconceitual. Para Sellars - e aqui se trata de uma posição muito importante para McDowell - o conteúdo proposicional de um juízo com o qual pretendemos conhecer os objetos mundanos exige ser justificado por algo com o qual mantenha uma conexão lógica de, digamos, dependência inferencial, algo de mesmo estatuto cognitivo, algo que seja também conceitual, o que conduz à desistência por uma justificação de conteúdos conceituais a partir de entidades não-conceituais, passíveis de um conhecimento imediato e indubitável.

Mas, para McDowell, a posição protagonizada por Sellars e mesmo por Davidson tem inconvenientes severos. O principal deles é o fato de que a ruptura com o dado bruto, quando compreendida como uma ruptura completa com o empirismo, compromete o realismo epistemológico, ou seja, acaba por conceber a aplicação dos conceitos como não restringida, não subordinada ao controle imposto pelo encadeamento dos eventos naturais. É digno de nota que esse inconveniente, essa tendência a se converter num "coerencialismo internalista" ${ }^{20}$, o qual faz com que se precipite sobre os críticos do "mito do dado" ${ }^{21}$ o risco de idealismo ${ }^{22}$, como já apontado por Habermas, seria e foi a primeira observação feita tradicionalmente a qualquer um que ousasse lançar mão da postura oferecida pela filosofia de Hegel. O curioso na complexa absorção de Hegel feita por McDowell é justamente que seu idealismo não sofreria desse risco de uma atividade conceitual completamente independente dos constrangimentos oferecidos pelo encadeamento empírico dos eventos. Surpreendentemente, no entanto, McDowell vê em Sellars e em Davidson esse risco, pois, ao abandonarem a noção de um dado não-conceitual

20 "A retórica coerencialista sugere imagens de confinamento nos limites da esfera do pensamento, enquanto opostas a estarem em contato com algo for a dele. Para aqueles que acham esta imagética tanto apropriada quanto preocupante, a ideia de dado pode fornecer a aparência de reinstaurar o apoio do pensamento na realidade." (McDOWELL, 1994, 15).

21 "Pode ser difícil aceitar que o mito do dado seja um mito. Pode parecer que se nós rejeitamos o dado, nós meramente nos expomos à ameaça de que nossa perspectiva não se acomoda a nenhum constrangimento externo sobre nossa atividade no pensamento e nos juízos empíricos. Pode parecer que nós estejamos retendo um papel para a espontaneidade ao recusarmos a reconhecer qualquer papel para a recepção, e isso é intolerável. Se nossa atividade no pensamento e nos juízos empíricos é para ser reconhecida como apoiando-se na realidade de uma maneira qualquer, tem de haver constrangimento externo." (McDOWELL, 1994, 9).

22 "Agora, pode parecer que a recusa em localizar a realidade perceptível fora da esfera conceitual tem de ser um tipo de idealismo, no sentido ... de que não pode reconhecer genuinamente como a realidade é independente de nosso pensamento ... Isso reflete a convicção de que nós temos de escolher entre uma recusa coerencialista de que pensar e julgar são sujeitos a constrangimento racional desde fora, de um lado, e o apelo ao dado que impõe constrangimento, de outro lado." (McDOWELL, 1994, 26-27). 
a partir do qual se poderia operar o controle e o constrangimento na aplicação dos conceitos que perfazem os juízos perceptivos, tendem a flertar com uma posição de difícil sustentação e segundo a qual a aplicação e uso desses conceitos procederia sem qualquer grau de subserviência em relação a uma realidade que permanece independente de nossas formas de representação. McDowell vê assim em Sellars o risco de um ensimesmamento e autonomização da atividade conceitual. Já Davidson McDowell o vê como tencionando uma solução que, noutro sentido, percebe-se também em Habermas e cuja problematicidade foi recentemente sublinhada por Bernstein ${ }^{23}$, a saber: a ideia de um atrito imposto em constrangimentos causais exercidos sobre os conceitos pela concatenação de eventos mundanos. Na opinião de McDowell, o que se veria perdido assim seria o componente normativo que a experiência incute na formação cognitiva de conceitos e que responde pela justificação das pretensões de objetividade. Mas o ponto da opção que eu estou sustentando é precisamente que ele nos faculta reconhecer que a realidade independente exerce um controle racional sobre nosso pensamento, mas sem recair na confusão entre justificação e desculpa que caracteriza o "mito do dado" (McDOWELL, 1994, 26-27). Para McDowell, nosso conhecimento empírico responde normativamente às disposições mundanas, o que somente pode ser preservado numa postura que atente mais à continuidade conceitual entre os fornecimentos perceptivos e os juízos investidos com pretensão criticável de validade objetiva.

\subsection{A posição de McDowell, em termos do debate Kant-Hegel}

Em certo sentido, podemos tentar preliminarmente entender a tese central do esforço de McDowell como procurando preservar, num só lance, aquelas dimensões que num ou noutro caso ameaçam serem perdidas. "Uma genuína rota de fuga requereria que nós evitássemos

${ }^{23}$ Frente às tendências contextualistas e neo-hegelianas, Habermas demonstra preocupação em que a epistemologia faça jus a nossas "intuições realistas" (HABERMAS, 2004, 15). Recentemente, Bernstein mostrou, de forma convincente e detalhada, de que forma o esforço teórico compartilhado por Habermas, Apel e Putnam herda a crítica à concepção de verdade como correspondência, tal como proposta pelo pragmatismo de Peirce, vinculando a ênfase sobre intuições realistas com uma crítica ao representacionalismo, a qual faz apelo à explicitação da dimensão intersubjetiva da validade, ou seja, às práticas intersubjetivas de justificação (BERNSTEIN, 2011, 105-118). Bernstein faz uma contundente crítica à maneira como Habermas procura recentemente fazer jus a estas "intuições realistas" em sua pragmática formal (BERNSTEIN, 2011, 175 e seguintes). De maneira sistemática, Bernstein sustenta a tese de que esta combinação de propostas é entendida de forma a fazer justiça tanto ao entrelaçamento entre verdade e justificação, quanto à sua diferenciação categórica, numa tentativa de escapar tanto ao relativismo radical quanto ao contextualismo (BERNSTEIN, 2011, 113). Tanto para os autores em pauta quanto para o intérprete que acionei, as posições epistemológicas assumidas por Rorty são as mais representativas dessa tendência (BERNSTEIN, 2011, 177 e seguintes). 
o mito do dado, sem renunciar à pretensão de que a experiência é um constrangimento racional sobre o pensamento. Eu sugeri que nós podemos fazer isso se reconhecermos que as impressões do mundo sobre nossos sentidos são já possuidoras de conteúdo conceitual." (McDOWELL, 1994, 18). Por um lado, trata-se de defender a tese de que a natureza não apenas constrange causalmente a formação de nossos conceitos, mas também normativamente, isto é, imprime um ritmo racional na formação dos conceitos com os quais estruturamos os juízos perceptivos. Eis por que McDowell opta por algo que chama de "empirismo mínimo" (McDOWELL, 1994, XI), desprovido do significado que premissas empiristas têm para os defensores do mito do dado, que o consideram uma existência fundacional e de última instância na justificação das pretensões cognitivas, mas também a uma perspectiva naturalista: "A alternativa que eu proponho sustenta o pensamento rejeitado pelo naturalismo mais radical" (MW, XIX) "de que as relações que constituem o espaço lógico das razões são algo que não seja natural"24. A segunda diretriz delineada por McDowell acaba por conduzilo para um ambiente próximo aos debates travados na filosofia clássica alemã, em especial por Kant e Hegel. McDowell defende a ideia, que vai procurar justificar se apoiando no debate entre Kant e Hegel, de que a experiência somente pode efetuar um controle normativo sobre a formação de conceitos, mesmo um controle subserviente ao encadeamento dos eventos, caso ela, experiência, seja sempre, em todas as suas dimensões, algo estruturado conceitualmente ou protoconceitualmente. "A visão que eu estou recomendando consiste em que, mesmo sendo a experiência algo passivo, ela põe em operação capacidades que pertencem genuinamente à espontaneidade" (McDOWELL, 1994, 13). Se quisermos jogar atentamente o jogo de McDowell, podemos começar tentando enunciar isto tudo em terminologia kantiana, a qual constitui, afinal, o horizonte categorial no qual McDowell explicita, ao menos nas duas primeiras conferências de "Mente e Mundo", suas diretrizes mais fundamentais. Em alguns momentos, na primeira Crítica e na Lógica de 1800, Kant descreve o conceito como "representação universal" ou "representação refletida", ao passo que a intuição é considerada como "representação imediata" ou "singular" dos objetos ${ }^{25}$. Tudo se passa como se McDowell quisesse entender a perspectiva kantiana num grau maior de continuidade entre seus polos, o conceito e a intuição, do que aceitando o que Kant muitas vezes dá a entender, ainda que com algumas importantes exceções, a saber: que a intuição seria uma operação

${ }^{24}$ MCDOWELL 1994, XVIII.

25 Ver: KANT, 1968, III, 93 e KANT, 1968, IX, 91. 
cognitiva absolutamente não-conceitual, responsável apenas por fornecer aos conceitos seu conteúdo não estruturado conceitualmente. Jogar Kant contra ele mesmo seria pensar uma maior continuidade entre representações imediatas e mediadas, de tal maneira que a experiência pudesse ser entendida, em toda sua envergadura, do conceito à intuição, como desdobrando-se, explicita ou implicitamente, de maneira conceitual. Assim, embora McDowell veja a noção kantiana de experiência como podendo abrigar essa amplitude, considera que as estratégias mais gerais do transcendentalismo, operando numa enfática diferenciação entre forma e conteúdo, e entendendo a intuição apenas e tão somente como uma operação da receptividade das impressões que uma coisa fora das fronteiras do conceitual exerce sobre nossa capacidade perceptiva, acaba por produzir mais uma perspectiva subserviente ao mito do dado. "Apesar de a realidade ser independente de nosso pensamento, não é para ser afigurado como sendo um contorno que enfeixa a esfera conceitual" 26 . A posição defendida por Hegel sob o título de idealismo absoluto se torna interessante, nesse debate, justamente porque rejeita o ponto de vista de um idealismo subjetivo, preso ao enfático dualismo entre conceito e intuição. "Conteúdo representacional não pode ser posto dualisticamente em oposição contra o conceitual. Isto é obviamente assim, não importa quão receptivos nós sejamos à ideia de que algum conteúdo representacional é não-conceitual" 27.

Para McDowell, responder a questão acerca das insuficiências nos esforços de Kant consiste em entender se Kant atribui à receptividade com uma contribuição separada em sua conexão com a espontaneidade. A ambiguidade dessa resposta é central para a interpretação que McDowell tem de Kant. "Para Kant, experiência não se baseia em fundamentos últimos aos quais nós poderíamos apelar apontando para fora da esfera do conteúdo pensável"28. Eis por que McDowell pensa que, do ponto de vista da experiência, o pensamento de Kant se relaciona com nossa interação cognitiva com o mundo, e à primazia da cooperação de espontaneidade e receptividade, de conceito e intuição. "O que nós encontramos em Kant é precisamente a figura que venho recomendando: uma figura na qual a realidade não é localizada fora dos limites que enfeixam a esfera conceitual" 29 .

Contudo, de acordo com McDowell, esta tese potencialmente libertadora da "indelimitação do conceitual" é perdida na perspectiva transcendental. "Tão logo o suprassensível entra em cena, sua

\footnotetext{
26 McDOWELL, 1994, 26.

${ }^{27}$ McDOWELL, 1994, 3.

${ }^{28}$ McDOWELL, 1994, 41.

29 MCDOWELL, 1994, 41.
} 
independência radical em relação ao nosso pensamento tende a se apresentar como não mais do que a independência que qualquer realidade genuína tem de ter." ${ }^{30}$ Portanto, assim como a perspectiva transcendental ameaça a teoria de Kant com o mito do dado, reduzindo drasticamente nossa liberdade responsável no pensamento empírico, este ponto de vista da investigação filosófica de condições sensíveis e conceituais diferenciadas, também transforma a consideração kantiana do conhecimento empírico numa proposta idealista. "Eu penso que deva ser admitido que o efeito do arcabouço transcendental é tornar a filosofia de Kant idealista no sentido que eu venho considerando"31.

Nesse sentido, o Hegel de McDowell, muito longe de sucumbir, devido ao seu idealismo, a uma perspectiva caracterizada como um giro sem atrito no vazio e, portanto, incompatível com o realismo epistemológico, seria capaz de algumas proezas promissoras do ponto de vista da administração do problemático legado da filosofia analítica. Primeiramente, por entender a experiência, desde estágios mais imediatos até os mais mediatizados, como desdobrando-se conceitualmente, a perspectiva defendida por Hegel não poderia ser exatamente acusada de falta de constrangimento objetivo, uma vez que empreenderia, antes, uma reação conceitual ao mundo, tal como ele se apresenta na experiência. Nesse sentido, estaria em Hegel uma expectativa que McDowell pretende resgatar e radicalizar, a ideia de que o mundo é feito do tipo de coisas que podemos pensar e compreender conceitualmente. Em segundo lugar, a perspectiva defendida por Hegel neutralizaria a principal deficiência da investida kantiana contra o empirismo, a saber: a ideia de que o domínio conceitual, que estrutura a experiência, é limitado por fora, isto é, limitado exteriormente por um domínio estático, ontológico e não-conceitual, passível de conceituação apenas negativa. Em terceiro lugar, Hegel proporia uma direção para a reconexão da discussão epistemológica na filosofia analítica com um tema grandioso, porém heterodoxo, considerado ao longo de toda a produção teórica de Wittgenstein, dos anos 30 aos anos 50, a saber: a ideia de uma sempre fluida e passível de deslocamento, nunca absoluta, linha fronteiriça entre o mental e o mundano, o sígnico e o imagético, o conceitual e o intuitivo, o linguístico e o ontológico. $\mathrm{Na}$ verdade, essa fluidez é a alma movente de uma das ideias mais explosivas de McDowell e de sua forma específica de considerar a formação dos juízos perceptivos, a ideia de que a experiência perceptiva, mesmo tendo um momento caracterizado pela passividade, é atualização de capacidades conceituais ou, por isso mesmo, protoconceituais.

30 McDOWELL, 1994, 42.

31 McDOWELL, 1994, 44. 
"É central para o idealismo alemão rejeitar a ideia de que o âmbito conceitual tem um contorno exterior"32. Em Having the World in View, McDowell desenvolveu uma ainda mais detalhada consideração da necessidade de acertar as contas com a maneira pela qual Hegel pensa na epistemologia. Baseado na alegação de Hegel de que Kant adota a assim chamada tese semântica do idealismo, McDowell sustenta que "Kant explica a pertença por parte da experiência de pretensão de objetividade ... em termos da ideia de que intuições são estruturadas pelas categorias", "em termos de suas unidades lógicas exemplificadoras que são características do julgar" ${ }^{33}$.

McDowell entende a reformulada dedução das categorias, a assim chamada versão $B$, como uma reação kantiana a uma incipiente e talvez plausível crítica de idealismo subjetivo. "Evocando a unidade da apercepção nós nos capacitamos a fazer sentido da pretensão de objetividade de intuições e a pretensão de objetividade dos julgamentos em conjunto" 34 . Contudo, apesar do foco na dedução da atividade intelectual autoconsciente, Kant desenvolveu um conjunto diferenciado de condições na Estética Transcendental, não relacionada à pensabilidade dos objetos, mas à sua dadidade.

Para McDowell, a versão B da dedução de Kant é, por assim dizer, reativa ao risco de idealism subjetivo, porquanto é lá que Kant pretende negar que a Estética Transcendental "ofereça uma condição independente para objetos serem dados aos nossos sentidos" 35 . De acordo com McDowell, o decisivo movimento na versão B da dedução consiste no argumento de que "a unidade constituída pela conformidade aos requisitos de nossa sensibilidade, os quais consistem na unidade das intuições formais puras de espaço e tempo, não são uma unidade separada, independente da unidade que consiste em ser estruturadas pelas categorias." 36

O fato de que a teoria kantiana na sensibilidade fique aquém do equilíbrio e simetria entre sujeito e objeto ${ }^{37}$, que Hegel reivindicou como

32 McDOWELL, 1994, 44.

33 MCDOWELL, 2009, 70.

${ }^{34}$ McDOWELL, 2009, 71.

35 McDOWELL, 2009, 71.

36 McDOWELL, 2009, 74.

37 "Um genuíno contrapeso entre o subjetivo e objetivo exigiria descartar a distinção kantiana entre coisas como elas são enquanto acessíveis aos nossos sentidos e as coisas tais como possam ser em si mesmas. Não exigiria deixar o caráter espacial e temporal de nossa sensibilidade fora do escopo da liberdade intelectual. Aqui nós podemos começar a perceber a questão de insistir em que não há nada fora do livre desdobramento do conceito. Conhecimento absoluto é a contrapartida integral da atividade de espontaneidade aperceptiva, tal como Kant a concebe na dedução transcendental, onde, justamente porque o caráter específico de nossa sensibilidade é deixado fora de seu escopo, o tencionado equilíbrio entre subjetivo e objetivo não é genuinamente alcançado." (McDOWELL, 2009,152). 
echter Idealismus, transforma os esforços de Kant em algo próximo de um "psicologismo subjetivista" ${ }^{38}$ e, de forma inesperada, faz com que Kant incorra no risco coerencialista de projetivismo ${ }^{39}$. Para McDowell, a tese kantiana de idealidade do espaço e do tempo, em comparação com um engajamento entre espontaneidade e receptividade, soa constitutiva da experiência apenas como uma "imposição subjetiva"40. A Estética Transcendental, à qual Kant apela por toda primeira Crítica a fim de domesticar o uso metafísico das categorias, é o ponto onde a Crítica reinstaura o mito do dado, Kant concebe a matéria como tendo sua forma própria, anterior à unidade que estrutura as intuições formais ${ }^{41}$. De maneira irônica, o que estabelece para Kant a compatibilidade entre idealismo transcendental e realismo empírico - a alegada idealidade de espaço e tempo como formas puras da intuição sensível - é o que McDowell percebe como vinculando o idealismo de Kant ao subjetivismo.

38 McDOWELL, 2009, 76.

39 "A integralidade hegeliana traz tudo para o interior do escopo da atividade livre subjetiva. Se alguém toma tal descrição fora do contexto, pode parecer que o movimento abandona o realismo do senso comum - que isso oblitera qualquer coisa genuinamente reconhecível como realidade objetiva, e isso a favor de projeções de movimentos não constrangidos da mente. Mas isso é desmentido pelo contexto. É a parcialidade kantiana que estraga sua tentativa de um equilíbrio entre subjetivo e objetivo. Expandir o escopo da liberdade intelectual não é um fator preponderante para o lado subjetivo, como se o objetivo ... pudesse ser apenas uma projeção da atividade subjetiva, considerado como inteligível de maneira independente. Isto é o que propriamente acontece na malsucedida tentativa kantiana por um equilíbrio. Porque há na base da construção kantiana uma subjetividade não assimilada, ela resulta em não mais do que em idealismo subjetivo. Esta é uma acusação hegeliana frequentemente considerada como ultrajante, mas nós agora nos encontramos em posição de encontrar justiça nela. A questão de expandir o escopo da liberdade intelectual é alcançar um equilíbrio genuíno entre o subjetivo e o objetivo, no qual nenhum dos dois é primordial. Alcançando um equilíbrio genuíno seria permitido à subjetividade ser concebida como engajada com o que é genuinamente objetivo. Sustentar que a própria ideia de objetividade pode ser compreendida apenas como parte de tal estrutura é exatamente não abandonar aquilo que é independentemente real em favor de projeções da subjetividade." (McDOWELL, 2009,152/153).

40 McDOWELL, 2009, 77 "Mas, em vista de sua doutrina de que nossa sensibilidade é da maneira como ela é independentemente do caráter das coisas em si mesmas, e independentemente de nossa capacidade para unificação aperceptiva, para a qual ela fornece materiais, isto significa que há uma subjetividade não assimilada, uma subjetividade sem nenhuma objetividade que a contrabalanceei, nos limites daquilo que pretendesse ser o lado objetivo de um contrapeso proto-hegeliano. O máximo que Kant pode reivindicar estabelecer na dedução é que não há nenhuma imposição extra-subjetiva em exigir que os objetos de nossa experiência conformem-se às requisições do entendimento, acima e além da imposição subjetiva envolvida no requerimento de que nosso mundo seja ordenado espacial e temporalmente. Mas este último é, como Kant o concebe, uma imposição subjetiva. Há uma simples reflexão acerca de um fato a nosso respeito no fundamento da construção kantiana. E, correspondentemente a esta subjetividade não assimilada no pretenso polo objetivo do tencionado contrapeso, há uma objetividade não assimilada, a coisa em si talvez não espacial nem temporal, deixada totalmente fora do contrapeso, e parecendo como se devesse ser um artigo genuíno." (McDOWELL, 2009,151).

41 McDOWELL, 2009, 79. 
Em Having the World in View, McDowell recupera sua defesa de Hegel em relação à acusação de que ele compreende objetividade como uma projeção da mente, resultante de movimentos conceituais não constrangidos. Mais uma vez, a acusação apela ao mito do dado a fim de assegurar o realismo do senso comum acerca da validade objetiva. Contudo, de acordo com Hegel e McDowell, quando assumimos que há uma realidade fora dos limites da esfera conceitual, nós perdemos também o âmbito genuíno da experiência, compreendido aqui como interação ente conceito e intuição: a dimensão de nosso engajamento conceitual com o mundo.

A concepção de experiência em McDowell, inspirada por Kant e radicalizada por Hegel, pretende ser um guia genuíno para a investigação empírica ${ }^{42}$, considerando, à luz da indelimitação do conceitual, "o mundo que experienciamos como medium nos limites do qual a liberdade da espontaneidade aperceptiva é exercitada" 43 . Ele refuta a acusação de idealismo extremo com a ideia de que nossa sensibilidade é reconcebida como "'momento' da livre autodeterminação da razão"44. "O ponto de vista do conhecimento absoluto é o ponto de vista no qual nós entendemos que a persecução de objetividade é o livre desdobramento do conceito. Não é o ponto de vista no qual nós tenhamos, de alguma forma, removido a nós mesmos do mundo empírico. Se o caso da persecução da objetividade que nós estamos considerando é a pesquisa científica, nós já estamos engajados com o mundo participando do conhecimento absoluto"45.

Em comparação com o idealismo de Kant, a filosofia de Hegel não fica aquém da tese semântica do idealismo, da ideia de que o si e os conceitos são isomórficos, mas apresenta a estrutura daquilo que Kant ele próprio chamou de unidade originária da apercepção transcendental, a qual também constitui o ponto de partida da dedução transcendental das categorias empreendida por Kant. O argumento de McDowell compreende o idealismo absoluto como uma tese filosófica simétrica, compatível com o realismo epistemológico.

42 "Parte da ideia de que o entendimento é uma faculdade de espontaneidade ... consiste em que aquela rede, tal como um pensante individual a encontra como governando seu pensamento, não é sacrossanta. Pensamento empírico ativo tem lugar sob a contínua obrigação de refletir sobre as credenciais das ligações supostamente racionais, caso isso seja o que a reflexão recomenda. Sem dúvida, não há nenhum prospecto sério de que precisemos reconfigurar os conceitos nos mais extremos cumes do sistema, os conceitos mais imediatamente observacionais, em resposta a pressões de dentro do sistema." (McDOWELL, 1994, 12-13).

${ }_{43}$ McDOWELL, 2009, 79.

44 McDOWELL, 2009, 86.

45 McDOWELL, 2009, 86. 


\subsection{0 recurso ao argumento da linguagem privada}

A tese de McDowell, que até soa muito próxima a Hegel, a tese de uma indelimitação do conceitual como estrutura fundamental da experiência perceptiva, é o motivo central para o enfático recurso feito por McDowell ao argumento wittegensteiniano da linguagem privada, contido nos §§ 244-315 das Investigações, como forma de neutralizar a concepção empirista e atomista da experiência externa e interna das qualidades secundárias, em especial, da percepção de cores. Sabemos que o argumento de Wittgenstein compõe uma estratégia mais ampla de ataque e reversão do atomismo lógico, defendido pelo Tractatus e por Russell, uma estratégia que resulta numa compreensão pragmática da linguagem, refratária ao nominalismo e ao referencialismo, constituindo a base para aquilo que vai ser posteriormente chamado de holismo semântico, especialmente visível na discussão do caráter público da atividade de seguir regras e na referência indefinida que necessariamente se estabelece entre elas. Na verdade, o argumento de Wittgenstein acaba por demonstrar não a irrelevância ou a inexistência das representações de acesso imediato e privado, mas sim sua relação intrínseca e constitutiva com representações conceituais. A maior consequência disso para uma compreensão atomista das qualidades secundárias e das cores é, como mostra Wittgenstein desde sua referência ao Teeteto de Platão (§ 46), a ideia de que tais componentes da experiência perceptiva estão dispostos gramaticalmente, numa relação muito íntima com conceitos e com a linguagem para que possam e devam ser compreendidos imediatamente no modo atomista da simplicidade elementar, ou, tal como queria Russell, como sense-data cognoscíveis imediatamente por acquaintance e que constituiriam a base verificacional do falível conhecimento proposicional ou por descrições.

$\mathrm{O}$ argumento da linguagem privada em Wittgenstein ${ }^{46}$ corrobora a tendência, presente na "gramática das cores" dos "parágrafos sobre o Teeteto" 47 , de submissão originária de eventos vivenciados à estruturação pela normatividade conceitual da linguagem pública ${ }^{48}$. De acordo com McDowell, o argumento wittgensteiniano da linguagem privada pretende sustentar que "uma mera presença não pode fornecer um fornecimento

\footnotetext{
WITTGENSTEIN, 1984, 1, 357 e ss.

WITTGENSTEIN, 1984, 1, 265 e ss.

48 "Como nós podemos rejeitar o dado sem obliterar a consciência 'interna'? Para conferir às impressões do 'sentido interno' o papel correto na justificação de juízos, nós precisamos concebê-las, tais como as impressões do 'sentido externo', como já possuindo, elas mesmas, conteúdo conceitual. Para fornecer o necessário limite à liberdade da espontaneidade, nós precisamos insistir em que elas são, de fato, impressões, produtos da receptividade." (McDOWELL, 1994, 21-22).
} 
justificatório num repertório a partir de fora dele, o tipo da coisa que a conexão entre conceitos e espontaneidade nos impeliu a fazer"49. "Assim, o argumento da linguagem privada é apenas a rejeição do dado, na medida em que ele se apoia nas possibilidades da linguagem." 50

O interessante é perceber que o conluio armado por McDowell entre Wittgenstein e Hegel em torno da indelimitação do conceitual serve ao resgate de um dos mais interessantes e decisivos capítulos da moderna teoria do conhecimento, uma discussão que opõe Hume e Kant em torno do estatuto epistemológico das qualidades secundárias.

\subsection{Odebate entre Hume e Kant em torno do estatuto epistemológico da percepção de cores}

Penso que a verdadeira crítica de Kant a Hume pode ser compreendida como uma refutação do nivelamento solipsista da noção de experiência. "A experiência (Erfahrung) consiste na conexão sintética de fenômenos (percepções) numa consciência, enquanto a mesma é necessária" ${ }^{51}$. Como tal noção de experiência repousa sobre a unidade sintética de uma consciência geral pensada na categoria, Kant permite que se pense a estruturação conceitual da experiência. Assim, seguindo uma colateral sugestão de Hume de que os "princípios de associação das percepções" talvez pudessem ser visualizados nas estruturas da linguagem corrente ${ }^{52}$, Kant chega a admitir que as categorias "servem ... apenas para soletrar fenômenos, a fim de que possam ser lidos como experiência" ${ }^{3}$. Talvez, justamente por isso, "tirar do conhecimento comum os conceitos que não se fundam em nenhuma experiência particular, e que, no entanto, aparecem em todo conhecimento de experiência, do qual constituem ao mesmo tempo a simples forma da conexão, não pressupõe maior reflexão

49 MCDOWELL, 1994, 20.

50 McDOWELL, 1994, 20.

51 KANT, 1968, AA, IV, 305.

52 HUME, 2007, 19 e seg. Depois de sustentar que "é evidente que existe um princípio de conexão entre os diversos pensamentos ou ideias", Hume se utiliza da seguinte ilustração para justificar seu estatuto epistêmico não inatista: "Se nos déssemos ao trabalho de transcrever a mais livre e descosida das conversas, observaríamos imediatamente que havia um elo qualquer a ligá-la em todas as suas transições. E, se tal elo faltasse, a pessoa que rompeu o fio condutor do discurso poderia informar-nos de que uma sucessão de ideias se desenvolvera em segredo na sua mente, afastando-a pouco a pouco do assunto, da conversa. Entre as diversas línguas, mesmo quando não se pode suspeitar da menor conexão ou comunicação entre elas, observa-se que as palavras que expressam as ideias mais complexas correspondem, sem problemas, aproximadamente umas às outras: prova concludente de que as ideias simples compreendidas nas ideias mais complexas foram ligadas por algum princípio universal cuja ação abrange por igual toda a humanidade" (HUME, 2007, 19 e seg). Trata-se da única saída para alguém que, como Hume, deseja "enumeração completa" dos princípios, sem ter de aderir ao inatismo das "operações do entendimento" (HUME, 2007, 28): localizá-los nas "leis imanentes do diálogo", ou nas línguas naturais tornadas pura exterioridade fenomênica.

53 KANT, 1968, AA, IV, 312. 
ou compreensão do que tirar de uma língua as regras do uso real das palavras em geral, e, assim, reunir os elementos de uma gramática (na verdade, ambas as operações estão muito intimamente ligadas)" 54 .

Sustentando que o conhecimento imediato de objetos é impossível ${ }^{55}$, e que a validade objetiva da experiência depende de sua estrutura conceitual, a solução kantiana do problema de Hume antecipa Hegel, Wittgenstein e McDowell. Isto é verdadeiro sobretudo no que concerne à ideia de que experiências internas e externas são condicionadas e estruturadas conceitualmente. Por conseguinte, a compreensão da experiência que lhe atribui uma natureza radicalmente intuitiva, privada e não-conceitual, cria déficits de justificação. Inserindo-se num ensejo criado pelo próprio Hume, ao mencionar o exemplo do "matiz de azul" como um "fenômeno contraditório que talvez prove não ser de todo impossível que uma ideia surja sem a correspondente impressão"56 exemplo cujas consequências plenas são sistematizadas por Kant sob o título de Antizipationen der Wahrnehmung ${ }^{57}$-, McDowell promove uma discussão, fortemente influenciada por Hegel e Wittgenstein, no sentido de neutralizar o caráter não-conceitual da experiência de percepção de cores e, em geral, das qualidades secundárias, sobretudo naquilo que elas encorajam em termos de uma expectativa por acesso imediato, indubitável e atomista.

Discutindo as "Antecipações da Percepção", na primeira Crítica, Kant sustenta que "em todos os fenômenos, o real, o qual é um objeto de sensação, tem grandeza intensiva, isto é, um grau" ${ }^{58}$. Poderíamos interpretar esta conclusão como um argumento proto-contextualista, pois Kant parece estar sustentando que o conhecimento perceptivo, ou mesmo a sensação, somente é possível quando estruturado pelas categorias de qualidade, as quais impõem a continuidade da matéria sensorial e, correspondentemente, a localização efetiva ou possível da referência no "espectro", por assim dizer. "Toda realidade na percepção tem um grau, entre o qual e a negação há uma gradação infinita de cada vez menores graus" 59 .

54 KANT, 1968, AA, IV, 322/323, grifo meu.

55 KANT, 1968, AA, IV, 299.

56 HUME, 2007, 14 e seg. É interessante notar como Hume, após expor seu exemplo de um fenômeno contraditório, como que antecipando todas as dificuldades contidas nesta sua tendência a minimizar as arestas do empirismo, diz: "creio que poucos negarão essa possibilidade; e isso servirá talvez como prova de que as ideias simples não derivam sempre e em todos os casos das correspondentes impressões; se bem que este exemplo seja tão singular que mal merece que nos detenhamos nele e alteremos, por sua causa, o nosso princípio geral" (HUME, 2007, 18).

57 KANT, 1968, III, 153.

58 KANT, 1968, III, 153.

59 KANT, 1968, III, 153. 
Talvez pudéssemos dizer, com Wittgenstein, que "uma mancha no campo visual, apesar de não precisar ser vermelho, tem de ter alguma cor: é, por assim dizer, circundado pelo espaço das cores" ${ }^{60}$. McDowell tende a radicalizar esta linha de raciocínio argumentando que "nós temos de entender qualquer experiência particular de qualidade secundária contra um pano de fundo de outras experiências de qualidade secundária, possíveis ou atuais"61.

McDowell tenciona não apenas neutralizar a tese de que as qualidades secundárias tenham um caráter não-conceitual, eliminando com isso a expectativa atomista por um acesso imediato, direto e indubitável, mas também delinear uma posição contextualista, baseada num acesso que é mediado por um sistema de conceitos empíricos. "Nós simplesmente supomos que eles vêm somente enquanto elementos de um conglomerado de conceitos que precisam ser adquiridos conjuntamente" 62 , assim como diz McDowell. De acordo com ele, mesmo na percepção de cores, "onde as ligações no sistema como um todo são mínimas, as capacidades conceituais relevantes são integradas na espontaneidade em sentido amplo, de um modo que faculta ao sujeito entender experiências nas quais estas capacidades são postas em operação como relances" 63 .

\section{Uma interpretação de Hegel a partir das indicações de McDowell: dialética especulativa e conhecimento perceptivo}

Recuperando o desenvolvimento geral pretendido por Hegel nos dois primeiros capítulos da Fenomenologia, gostaria de mostrar, a partir da leitura de McDowell, o ponto mais geral do argumento como sendo uma crítica à noção kantiana de intuição empírica, quando considerada como instância não-conceitual, um resultado muito importante para McDowell e sua tese acerca da atualização de capacidades conceituais ${ }^{64}$ na percepção e que representa uma forte aproximação dele com o esforço hegeliano e com certo legado aristotélico. "Receptividade não faz nem mesmo uma contribuição conceitualmente separada na cooperação" 65 . Trata-se, assim, de uma leitura aristotélica da efetivação de capacidades conceituais, as

\footnotetext{
60 2.01.31,WITTGENSTEIN, 1984, 1, 12.

61 MCDOWELL, 1994, 32.

62 MCDOWELL, 1994, 31.

63 McDOWELL, 1994, 31-32.

64 "As capacidades conceituais de uma pessoa já tem de ter sido postas em movimento, apenas para que o conteúdo já esteja acessível, antes que se tenha alguma escolha no assunto ... de fato, é precisamente porque a experiência é passiva, um caso de receptividade em operação, que a concepção de experiência que eu estou recomendando pode satisfazer a exigência por um limite à liberdade que subjaz ao mito do dado." (McDOWELL, 1994, 10).

65 McDOWELL, 1994, 9.
} 
quais dispostas sistemicamente, sem que se incorra, entretanto, no risco de abolir o realismo em virtude de um contextualismo radical ${ }^{66}$.

A "dialética da certeza sensível" 67 é um momento paradigmático para se compreender a relação entre experiência e a linguagem, ou seja, em que sentido a experiência se estrutura de maneira necessariamente conceitual $^{68}$. Em sua forma mais radical, a certeza sensível ergue a pretensão "eu sou puro intuir"69. A certeza sensível é a "história de sua experiência"70, a saber: aqueles que defendem qualquer forma autossuficiente de conhecimento imediato, sobre "coisas efetivas, absolutamente singulares, totalmente pessoais e individuais ... não dizem aquilo que visam. Se eles efetivamente quisessem dizer este pedaço de papel, o qual visam - e eles quereriam dizê-lo - então isso é impossível, pois o isto sensível, que é visado, é inalcançável à linguagem, a qual pertence à consciência, àquilo /[que é] em si universal ... eles dizem delas somente o universal. Por conseguinte, aquilo que é denominado inexprimível (das Unaussprechliche) nada mais é do que o não-verdadeiro, não-racional, simplesmente visado." 71 É claro que, no itinerário de figuras da consciência, o resultado imediato dessa experiência é a percepção da coisa pela mediação da propriedade (Eigenschaft $)^{72}$. Mas na "experiência da certeza sensível" 73 se insinua, sobretudo para o "nós fenomenológico", "o falar, que tem uma natureza divina"74. Sendo assim, a experiência da pretensão do puro intuir é a mediação linguística, em sua acepção mais geral. Parece-nos plausível a tese, defendida entre os seguidores de Sellars, de que o desenvolvimento da consciência em direção à "percepção" e ao "entendimento" na Fenomenologia conteria uma ilustração do "contextualismo cognitivo" de Hegel"15. Sobre este tópico, faço referência à discussão feita por Brandom sobre a articulação da noção de incompatibilidade material, enquanto o que permite a plena determinação de um conteúdo como plenamente

\footnotetext{
66 "As capacidade conceituais que são passivamente postas em movimento na experiência pertencem a uma rede de capacidades para o pensar ativo, uma rede que racionalmente governa a compreensão buscando respostas aos impactos do mundo sobre a sensibilidade." (McDOWELL, 1994, 12).

67 HEGEL, 1970, 3, p. 87.

68 "Linguagem" entendida no bojo de uma teoria geral da "mediação" (Vermittlung) enquanto "passagem" (Übergang) de "palavras que só exprimem (ausdrücken) a intuição como algo imediato, mesmo que seja somente passagem para outra proposição" (idem, op. cit., 24).

69 Idem, op. cit., 87.

70 Idem, op. cit., 89.

${ }^{71}$ Idem, op. cit., 90-91.

72 Idem, op. cit., 93.

73 Idem, op. cit., 87.

${ }^{74}$ Idem, op. cit., 91.

75 REDDING, 2007, 18.
} 
individuado, ou, segundo Brandom, aquilo que Hegel chama de negação determinada, diferenciando-o da simples negação de propriedades no capítulo sobre a "Percepção"76 e em relação ao que ocorre no capítulo sobre o "Entendimento".

Redding mostrou recentemente como McDowell interpreta a passagem hegeliana da "certeza sensível" para a "percepção" numa linha favorecida por sua longa colaboração com Gareth Evans numa discussão crítica do estatuto epistêmico dos termos indexicais tais como defendidos pelo atomismo lógico de Russell. Para Russell, os termos demonstrativos denotam elementos do real que acessamos imediatamente, mesmo por definição ostensiva. Com a ajuda de Evans, McDowell quer mostrar que o conceito hegeliano de objeto da percepção contém uma contundente crítica a essa ideia, já que rompe com a noção de autosustentabilidade do singular imediato na direção de uma reconhecível mediação conceitual do que seria a noção kantiana de intuição empírica. Assim, Hegel colaboraria para que o conceito de intuição proveniente de Kant perdesse seu caráter não-conceitual, tornando-se um demonstrativo no qual a coisa atualiza suas propriedades gerais. Isso representa, mostrou Redding, uma dupla aproximação a Aristóteles. Primeiro, porque o conceito hegeliano de objeto percebido, um particular que teve sua singularidade mediada conceitualmente, aproxima-se do que Aristóteles pretende com o Tode ti ou com a ideia de uma substância individual enquanto sínolon, enquanto amálgama de matéria e forma. Por outro lado, essa compreensão aristotelizante do resultado alcançado por Hegel acaba por fornecer uma ilustração mais rica daquilo que McDowell deseja defender com a tese de que no conhecimento perceptivo a receptividade de fornecimentos mundanos provoca uma atualização de capacidades cognitivas, em particular, no caso do desenvolvimento dado por Hegel, os recursos classificatórios dos objetos particulares que são imanentes ao contexto formado por estas entidades não imediatamente singulares ${ }^{77}$.

Nas Investigações Filosóficas, Wittgenstein resumiu o componente semântico da teoria pragmática da percepção sustentando que a descrição tem primazia sobre a denominação ( $\S 49$ ). Por outro lado, Redding sustenta que o aristotelismo de McDowell o impede de compreender o ponto de Hegel em toda a sua significância. "McDowell segue o criticismo hegeliano da certeza sensível ao afirmar a natureza conceitual da experiência perceptiva, mas ele ignora as diferenças nas maneiras pelas quais o conteúdo cognitivo pode ser conceitual para os quais Hegel sinaliza na diferença entre percepção e entendimento. Para McDowell

\footnotetext{
76 BRANDOM, 2002, 179, 180, 184.

77 REDDING, 2007, 29-55.
} 
(mas não para Hegel) conteúdo perceptivo não é apenas conceitual, mas também proposicional"78.

Penso que aquilo que McDowell diz sobre o caráter conceitual e proposicional do conteúdo perceptivo não é tudo o que pode ser dito sobre os desdobramentos propostos por Hegel na Fenomenologia. No entanto, se se observa a afirmação de Hegel de que a oscilação do "entendimento perceptivo" (wahrnehmender Verstand) é devida à "lógica da percepção"

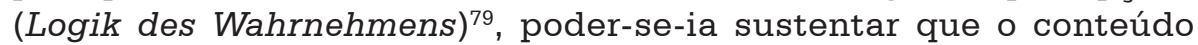
perceptivo tem uma estrutura proto-proposicional, e que ele falha em compreender as relações inferenciais entre proposições por causa de sua orientação em termos de uma lógica de termos. Eu penso que esta ideia é compatível como o contextualismo de McDowell, o qual sustenta que a experiência perceptiva é mediada por um sistema integrado de conceitos empíricos.

\section{A interpretação de Hegel em Having the Word in View: da tese semântica do idealismo à compreensão alegórica da dialética entre senhor e escravo}

Gostaria agora de mostrar como McDowell aprofunda sua percepção do debate entre Kant e Hegel num trabalho mais recente, Having the Word in View. Creio que McDowell enriqueça consideravelmente sua perspectiva hegeliana fazendo com que a discussão nutrida por Hegel a respeito da natureza subjetivista do idealismo kantiano desemboque numa idiossincrática interpretação da dialética do senhor e do escravo, a qual ele chama de "alegórica".

\subsection{A tese semântica do Idealismo}

Aquilo que Hegel vê de formidável na perspectiva kantiana consiste, de acordo com McDowell e tantos outros, como Brandom e Bernstein, no que atualmente é chamado de tese semântica do idealismo.

A tese semântica do idealismo, a qual identifica a unidade do sujeito com a unidade do conceito, é a consumação do pensamento da identidade ... Trata-se do princípio fundante tanto da filosofia de Kant quanto da de Hegel. Na filosofia de Kant, o ponto de concentração está na unidade do sujeito, da unidade transcendental da apercepção, enquanto fonte da unidade do conceito; em Hegel, especialmente na Ciência da Lógica, é o próprio conceito que entra em cena como elemento fundante (grundlegend) $^{30}$.

\footnotetext{
78 REDDING, 2010, 580.

79 HEGEL, 1970, 3, 104.

80 BERNSTEIN, 2006, 95.
} 
A percepção que McDowell tem do debate entre Kant e Hegel segue, em muitos sentidos, aquilo que o próprio Hegel tem para dizer a respeito. Por um lado, Kant alcança, ao formular a tese semântica do idealismo, a posição filosófica autêntica. Por outro lado, ao manter a perspectiva transcendental centrada nas afecções provenientes de uma coisa em si, acaba por padecer de um desequilíbrio entre os componentes subjetivo e objetivo da cognição, os quais Hegel desejaria ver equilibrados e reciprocamente determinados em seu conceito de saber absoluto, pelo que Kant cai, para McDowell e Hegel, numa perspectiva idealista, mas subjetiva. A seguir, vou retomar alguns traços decisivos da crítica de Hegel a Kant em textos canônicos, para então, depois disso, considerar as questões postas por McDowell.

\subsection{A crítica de Hegel a Kant}

Desde os escritos de Jena, na equação cisão/entendimento versus unificação/razão, que se conecta com uma diferente localização da "faculdade" propriamente filosófica, está contida a ideia fundamental da crítica hegeliana à filosofia de Kant e Fichte. Com respeito à filosofia de Kant, Hegel diz que, "no princípio da dedução das categorias esta filosofia é autêntico idealismo (echter Idealismus), e este princípio é aquilo que Fichte acentuou de forma pura e rigorosa e chamou de espírito da filosofia kantiana" 1 . No entanto - e aqui reside, no registro próprio à "filosofia teórica", o núcleo de toda sua crítica especulativa às insuficiências da filosofia da reflexão -, "permanece exterior às determinações subjetivas pelas categorias um formidável reino da sensibilidade e da percepção, uma absoluta aposterioridade ... isto é, a não identidade é elevada a princípio absoluto" ${ }^{82}$. Deste modo, a apreciação geral do idealismo de Kant e Fichte ${ }^{83}$ oscila entre o reconhecimento pelo fato de que na "dedução das formas do entendimento o princípio da especulação, a identidade do sujeito e objeto, é pronunciada da maneira mais determinada"84; e a constatação de que em seu desenvolvimento o sistema se mantém aquém deste enunciado: "quando Kant faz desta identidade mesma, enquanto razão, objeto da reflexão filosófica, a identidade desaparece de junto de si mesma." ${ }^{85}$ Com efeito, apesar de alcançarem o "autêntico" princípio da

81 HEGEL, 1970, 2, 9.

82 HEGEL, 1970, 2, 10.

83 Acerca desta congruência de Kant e Fichte na consecução do "autêntico" princípio da especulação, Hegel diz, em relação a Fichte, que: "O puro pensar a si mesmo, a identidade do sujeito e do objeto na forma $\mathrm{Eu}=\mathrm{Eu}$ é o princípio do sistema fichteano, e se se atém imediatamente a este princípio - tal como, na filosofia kantiana, ao princípio transcendental, o qual jaz no fundamento da dedução das categorias - então se tem o autêntico princípio da especulação inovadoramente exprimido." (HEGEL, 1970, 2, 11).

84 HEGEL, 1970, 2, 10.

85 HEGEL, 1970, 2, 10 
especulação - onde se revela a "imitação" da razão pelo entendimento -, Kant e Fichte pretendem resolver a tarefa da razão, contida no princípio da identidade entre sujeito e objeto, através somente dos meios da reflexão.

É digno de nota que a crítica de Hegel a Kant tem, na maior parte das vezes em que ocorre, uma certa intimidade com a crítica feita ao empirismo e, em especial, a Hume. A artimanha de Hegel é motivada pela sua tese fundamental acerca de Hume e Kant: ambos os paradigmas filosóficos tematizados na "segunda posição" padecem de uma mesma patologia, a saber: a subserviência à diferença intransponível entre forma e conteúdo ${ }^{86}$, ao Unterschied der Elemente. Entretanto, enquanto a filosofia de Kant toma esta diferença reconhecidamente como ponto de partida, o empirismo é disto inconsciente, o que constitui sua ilusãofundamental (Grundtäuschung); pois o empirismo busca uma "realização consequente" 87 como compreensão epistemológica da ciência natural moderna, ou seja, como "wissenschaftlicher Empirismus"88.

A conclusão da crítica de Hegel a Hume é particularmente interessante para a formulação de sua concepção de uma perspectiva embasada na visualização dialética da suspensão da diferença entre forma e conteúdo. "[E]nquanto esse sensível é - e permanece - um dado (ein Gegebenes) para o empirismo, temos uma doutrina da não-liberdade, porque a liberdade consiste justamente em que eu não tenha diante de mim nada absolutamente outro, mas dependa de um conteúdo que sou eu mesmo"89.

Afora a referência a certa operacionalização lógico-epistêmica do conceito kantiano-rousseauísta de liberdade como autodeterminação, tantas vezes evocada por McDowell como "liberdade intelectual"90, neste texto fabuloso não somente fica clara a dívida de Hegel para

86 HEGEL, 1970, 8, 110.

87 HEGEL, 1970, 8, 107.

88 HEGEL, 1970, 8, 107. Por um lado, o empirismo "nega o suprassensível em geral, ou pelo menos seu conhecimento e sua determinidade, e só deixa ao pensar a abstração, e a universalidade e a identidade formais"; por outro lado, ao buscar embasar as pretensões de validade da ciência moderna, tem de "utilizar as categorias metafísicas de matéria, força, e também uno, múltiplo, universalidade, infinito etc... e, ainda mais, segue inferindo (fortschließt) pelo fio condutor de tais categorias, pressupondo e aplicando para isso a forma do inferir (Formen des Schließens) - / ainda mais que ele, em tudo isso, não compreende (weiß) que, desta maneira, ele próprio contém (enthält) e pratica metafísica, e emprega aquelas categorias e suas conexões de uma maneira totalmente acrítica e inconsciente." (HEGEL, 1970, 8, 107/108).

89 HEGEL, 1970, 8, 110.

90 "Se nossa liberdade no pensamento empírico é total, em particular se ele não é constrangido desde fora da esfera conceitual, isto parece ameaçar a própria possibilidade de que juízos de experiência pudessem ser fundados de uma maneira que os relaciona à realidade exterior ao pensamento. [...] O que nós gostaríamos de conceber como exercícios conceituais ameaça degenerar em movimentos de uma jogo auto-contido." (McDOWELL, 1994, 5). "Nós precisamos conceber esta espontaneidade expansiva como sujeita ao controle desde fora do pensamento, caso não queiramos arcar com a representação das operações da espontaneidade como um giro sem atrito no vazio." (McDOWELL, 1994, 11). 
com Kant na crítica ao empirismo, como também a ideia de que uma perspectiva mediacional é vinculada ao projeto de suspensão dos limites da explicação fornecida pelo empirismo para o modus operandi da ciência natural moderna, limites que são identificados pelo dado intransponível.

Eis aí, por conseguinte, uma caracterização mais cara à epistemologia contemporânea do caráter "mediacional" do pensamento infinito (unendliches Denken) ou da forma infinita ${ }^{91}$ que Hegel pretende substituir às "posições do pensamento com respeito à objetividade"92. Enquanto estas se aferram à "representação da época moderna, segundo a qual o pensar seria sempre limitado", o pensar infinito, "o pensar que está junto de si mesmo, consigo mesmo se relaciona ... tem a si mesmo por objeto", um "ein aufgehobener, ideeller Gegenstand"93.

Interessa-me aqui, sobretudo, sublinhar esta situação histórica à qual pretende responder o projeto hegeliano ${ }^{94}$. Não é simplesmente

91 "A ideia lógica tem, portanto, enquanto forma infinita, a si mesma por seu conteúdo - a forma que constitui a oposição ao conteúdo, enquanto este é, desta maneira, a determinação formal (Formbestimmung) que foi (a)dentro de si e suspensa na identidade, de tal maneira em que esta identidade concreta se encontra defronte à [identidade] desenvolvida como forma." (HEGEL, 1970, 6, 549). A forma infinita, uma noção à qual Hegel faz referência no capítulo final da Ciência da Lógica, é a forma reflexiva da ideia lógica enquanto idéia absoluta, que tem por único conteúdo a totalidade das determinações do conceito que se desenvolve em direção a ela; representa, portanto, não apenas o pleno desenvolvimento dessas determinações, mas o momento de autorreflexão, no qual e pelo qual ela se reconhece enquanto totalidade dessas determinações "formais", aliás, as mesmas como seu conteúdo último e único. Tratase, portanto, da forma conceitual que tem a identidade de forma e conteúdo por seu próprio conteúdo.

92 HEGEL, 1970, 8, 95.

93 HEGEL, 1970, 8, 95. Sendo assim, Hegel propõe uma lógica como "ciência da ideia pura" (HEGEL, 1970, 8, 66) que, "reunindo a atividade das formas do pensamento e sua crítica" (HEGEL, 1970, 8, 115), seja capaz de apresentar, de forma imanente, as mediações ou inferências necessárias, as quais são sempre intrínsecas à "experiência", trazendo à tona com isso a contribuição precisa dos conceitos puros e das inferências feitas a partir deles naquilo que é articulado intersubjetiva e linguisticamente como experiência humana. Tratase, portanto, num só lance, da ruptura com a epistemologia moderna, considerando-se suas decorrências linguísticas - e, num certo sentido, ontológicas; e, paradoxalmente, também da radicalização daquele projeto epistemológico, posto que inteiramente embasado no conceito de crítica e autorreferencialidade, na autonegatividade enquanto objeto da reflexão (PINKARD, 1996, 7), no operar sobre si o sich vollbringender Skeptizismus (HEGEL, 1970, $3,71)$.

94 "Ao próprio Kant faltou um sentido de historicidade dos modelos de conhecimento tomados como obrigantes (authoritatives), e assim como ele pensou que Aristóteles tinha estabelecido definitivamente as formas básicas da inferência correta, e Euclides as estruturas básicas do conhecimento geométrico, da mesma forma ele pensou que Newton tinha estabelecido definitivamente a ciência do mundo fenomênico. Olhando retrospectivamente a partir do século XX, contudo, nós percebemos bastante alteração histórica nos objetos da ciência para nos inclinar a concordar antes com Hegel do que com Kant neste assunto. E esta plasticidade das estruturas epistêmicas é, por sua vez, ligada ao fato de que uma "virada linguística" definitiva separa as respectivas propostas de Kant e Hegel, mais uma vez fazendo de Hegel o pensador do lado dos modernos." (REDDING, 2007, 10/11). Se aceitarmos que Hegel está 
uma alternativa à epistemologia moderna, mas, propriamente, sua konsequente Durchführung, sua "realização consequente" 95. Para Hegel, as ciências naturais modernas, essencialmente nomológicas e observacionais ${ }^{96}$, pressupõem, para a satisfação de suas demandas epistêmicas, as implicações da autorreferencialidade da experiência articulada linguisticamente, as decorrências da reflexão constitutiva. A "reflexão (Nachdenken) está sempre à busca do firme, do permanente, do determinado-dentro-de-si, e do que rege o particular. Esse universal não se pode captar com os sentidos, e vale como o universal e o verdadeiro."97 Neste sentido, o déficit epistemológico das pretensões de validade objetiva ocasionado pela transformação, tipicamente moderna, da observação em ciência nomológica é compensado por uma perspectiva mediacional, por meio da evidenciação do caráter mediacional ou inferencial $l^{98}$ daquilo que pode contar como experiência humana. "Ao determinar desse modo o universal, encontramos que ele forma o contrário de um outro, e que esse outro é o simplesmente imediato, exterior, e singular em face do mediatizado, interior e universal. Esse universal não existe externamente enquanto tal ... as leis do movimento dos corpos celestes não estão escritas no céu. O universal, pois, não se ouve nem se vê, mas é somente para o espírito" 99 .

Assim, a crítica de Kant proposta por McDowell encontra paralelos na caracterização feita por Hegel acerca da arbitrariedade e ingenuidade da

mais interessado em revelar a sedimentação linguística da experiência humana em sua historicidade, poderíamos dar razão a Redding a partir de Habermas, que sustenta, também retrospectivamente, como dado incontornável da situação epistemológica contemporânea, a necessidade de compatibilização do realismo epistemológico com a "descoberta da filosofia da linguagem segundo a qual nos é negado um acesso direto, não mediatizado pela linguagem, à realidade 'nua'" (HABERMAS, 2004, 5).

95 HEGEL, 1970, 8, 107.

96 “Também encontramos o mesmo em nosso proceder em relação aos fenômenos naturais ... o homem não se contenta com o simples conhecimento habitual, com o fenômeno sensível apenas, mas quer ver o que está por trás para saber o que ele é: quer conhecê-lo. Por isso se reflete, quer-se saber a causa, como algo diferente do fenômeno enquanto tal; quer-se saber o interior em sua diferença do puramente exterior. Desse modo, duplica-se o fenômeno; parte-se o fenômeno em dois - em interior e exterior, força e exteriorização, causa e efeito. O interior, a força, é aqui de novo o universal, o pensamento ... o sensível é um singular e evanescente, o que nele permanece aprendemos a conhecer pela reflexão. Mostra-nos a natureza uma infinita multidão de figuras e fenômenos singulares. Precisamos levar à unidade esta multiplicidade vária." (HEGEL, 1970, 8, 77).

97 HEGEL, 1970, 8, 77.

98 Sobre este assunto, ver a discussão feita por Brandom sobre o papel da mediação (Vermittlung) na "articulação inferencial de conteúdos induzida por relações de negação determinada", ou seja, segundo Brandom, relações de incompatibilidade material (BRANDOM, 2002, 181). Por conseguinte, entendida desta forma, a incompatibilidade material se tornaria, para Hegel, a estrutura normativa mais fundamental dos conteúdos conceituais.

99 HEGEL, 1970, 8, 77. 
perspectiva assumida pelo idealismo transcendental ${ }^{100}$, a qual encontra paralelos, por sua vez, como mostrou Redding e na medida em que conduz a certa psicologização da razão, na distinção enfática, feita por Frege, entre o Gedanke e a Vorstellung, perspectiva essa prescindível para uma teoria objetivista do sentido linguístico.

\subsection{A leitura alegórica da passagem do entendimento à consciência de si na Fenomenologia}

Finalmente, gostaria de reconstruir rapidamente a passagem, já no capítulo da "Consciência de Si", que antecipa a figura da dialética entre senhor e escravo. Ao longo dessa análise, vou procurar indicar onde as indicações heterodoxas de McDowell funcionam no sentido de abrir potenciais de interpretação.

Na "Consciência" da Fenomenologia, a experiência do entendimento desemboca na mediação do imediato consigo mesmo, da "infinitude simples - ou o conceito absoluto", o qual "... deve-se chamar a essência simples da vida, a alma do mundo, o sangue universal, que onipresente não é perturbado nem interrompido por nenhuma diferença, mas que antes é todas as diferenças como também seu ser-suspenso; assim, pulsa em si sem mover-se, treme em si sem inquietar-se." ${ }^{101}$ Assim, a infinitude, que era somente para nós, se tornou também para consciência. Para Hegel, é no recurso à explicação fenomênica do jogo de forças que a infinitude "surgiu, livre, pela primeira vez" ${ }^{102}$; pois o entendimento

${ }^{100}$ McDowell tende a interpretar a saída hegeliana no debate proposto por Kant a partir da compreensão desse debate proposta por Henry Allison. Em Kant's Transcendental Idealism, Allison considera a especificidade do idealismo transcendental de Kant a partir de uma diferenciação entre "condições de possibilidade do conhecimento das coisas" e "condições de possibilidade das coisas elas mesmas". Para Allison, a visão que Kant tem do racionalismo do XVII e XVIII consiste, em geral, em que o realismo transcendental confere primazia às condições de possibilidade das coisas elas mesmas, em detrimento das condições de possibilidade do conhecimento das coisas, sustentando, num sentido ainda radicalmente contemplativo na filosofia teórica, o caráter derivado das condições epistêmicas, passivamente dependentes de condições autônomas da possibilidade das coisas. Ora, segundo Allison, a manutenção do ponto de vista crítico de "espontaneidade" do conhecimento tem obrigatoriamente de insistir na distinção acima, caso contrário sobrevém a ameaça contraposta ao realismo transcendental: o subjetivismo fenomenalista. O que há aqui, segundo McDowell, é o não reconhecimento de uma alternativa, a hegeliana, a qual, embora não reconheça a distinção, não é nem um subjetivismo, nem um realismo transcendental. "Mas isso reflete a suposição de Allison de que qualquer tentativa de rejeitar a distinção permanecendo crítico somente pode ser a contrapartida simétrica ao realismo transcendental, tomando condições "subjetivas" como autônomas enquanto tais, ao passo que o realismo transcendental considera condições "objetivas" como sendo em si autônomas. O que está faltando é a alternativa hegeliana, a qual é inspirada pela maneira como Kant quer pensar as exigências do entendimento: de que as condições relevantes sejam inseparavelmente tanto condições sobre o pensamento quanto condições sobre os objetos, não primordialmente de um ou de outro" (McDOWELL, 2009, 80).

${ }^{101}$ HEGEL, 1970, 3, 131

102 HEGEL, 1970 3, 132 
experimenta, com a inversão do mundo decorrente da intenção estática da legalidade, a oposição absoluta entre fenômeno e essência, e contempla o surgimento de um objeto que é, na verdade, também ele mesmo: a vida, forma objetiva onde cada determinação reverte-se no contrário de si mesma, e "essa inquietação absoluta do puro mover-se-a-si-mesmo [faz] que tudo o que é determinado de qualquer modo ... seja antes o contrário dessa determinidade." ${ }^{103}$ Eis por que é gerada, com a transformação do objeto em si mesmo, uma relação que não é mais aquela entre consciência e objeto "sem consciência", mas a relação para si mesma, a essência da consciência-de-si: o entendimento descobre, na estrutura do "sero-oposto-de-si-mesmo", sua própria estrutura como consciência-de-si. "Quando a infinitude - como aquilo que ela é - finalmente é o objeto para a consciência, então a consciência é consciência-de-si" ${ }^{104}$. O entendimento se torna objeto de si mesmo e, nesta medida, não simplesmente objeto, mas também sujeito: "essa unidade é também ... seu repelir-se de si mesma; e esse conceito se fraciona na oposição entre a consciência-desi e a vida" 105 .

\begin{abstract}
A alteridade que confronta minha autoconsciência no início do capítulo é a alteridade do mundo como cenário da vida consciente - de fato, minha vida, ainda que demore um pouco até que essa especificação seja diretamente acessível. Quando 'toda a expansão do mundo sensível' retorna (a)dentro de si mesma e se torna vida, isso torna possível outra maneira de apontar para a alteridade, ao falar de uma antítese entre minha consciência e a vida consciente individual cujo cenário é meu mundo. É essa vida, ou o indivíduo vivendo-a, que é progressivamente revelado como sendo ele mesmo consciência e consciência de si. O que é efetivamente, é minha autoconsciência, não a de outra pessoa. Quando isso se torna claro, a consciência empírica será integrada com a consciência perceptiva, e a alteridade do mundo que confronta minha consciência empírica será expurgada de sua ameaça de abrir um fosso entre o subjetivo e objetivo ${ }^{106}$.
\end{abstract}

Na Fenomenologia, aprofunda-se a tese, advogada desde 1800, da individualidade como orgânica, como elemento vital. Por conseguinte, é na imediatez do substrato vital que a consciência-de-si, que dele emerge como uma modificação, vai levar à prova sua tese de que o verdadeiro ser não é um objeto contraposto (Gegenstand), e sim ela mesma. "A consciência-de-si é certa de si mesma, somente através do suprassumir desse Outro, que se lhe apresenta como vida independente:

\footnotetext{
${ }^{103}$ HEGEL, 1970 3, 131.

${ }^{104}$ HEGEL, 1970 3, 132.

${ }^{105}$ HEGEL, 1970 3, 138.

${ }^{106}$ McDOWELL, 2009, 160.
} 
a consciência-de-si é desejo." 107 O desejo é a forma mais elementar e imediata desta tentativa de verificação do caráter inessencial do ser-outro e da demonstração da sua dependência ao ser-para-si da consciência, isto é, de remoção da oposição entre a consciência e seu objeto. "Certa da nulidade desse Outro, põe para si tal nulidade como sua verdade; aniquila o objeto independente, e se outorga, com isso, a certeza de si mesma como verdadeira certeza, como uma certeza que lhe veio-a-ser de maneira objetiva." $108 \mathrm{O}$ movimento pelo qual a identidade abstrata vem a ser para a consciência, cuja essência é a reflexão sobre si a partir do mundo sensível, reclama a alteridade ou o momento da consciência como saber-do-outro, mas enquanto objeto a ser negado para que a consciência-de-si possa pôr, por esta negação, sua própria unidade consigo mesma. Desejo é a expressão imediata do movimento pelo qual o saber-de-si emerge do saber-do outro, isto é, pelo qual a consciência-de-si institui sua unidade consigo mesma através da negação do seu ser-outro, e o mundo perde sua subsistência em-si, permanecendo apenas como outro da consciência-de-si, dependente desta relação a ela.

Entretanto, atrelada à emergência da consciência desejante do meio vital está a tese de que "o que a consciência-de-si diferencia de si como sendo ... é também Ser refletido sobre si; o objeto do desejo imediato é um ser vivo." 109 "O tópico real concerne a dois aspectos de um indivíduo singular, ainda que isso, no estágio em que nos encontramos, não seja claro ao indivíduo em questão. O aparecimento imediato da consciência pensante marca uma integração temporária dos dois aspectos, uma consciência que previamente fora vista como meramente dependente do mundo, alcança um tipo de independência em sua atividade formativa, a qual se torna a liberdade de pensamento. Nós poderíamos colocar isso dizendo que uma consciência empírica se torna uma consciência aperceptiva." 110 Segundo Hegel, a universalidade imediata ou singularidade da consciência-de-si emergente da vida opõe-se, como puro ser para si, à vida universal e tem a pretensão de se pôr absolutamente para si, o que a levará a experimentar a obstinação deste objeto em corroborar-lhe a certeza de sua independência. Aquilo com que a consciência-de-si se depara como o outro do eu é a vida em geral, aquilo que é o mesmo e o outro de si. Ao desejar a vida, a consciência de si deseja um outro cuja essência é poder ser ela mesma, e se apercebe de que justamente este objeto do desejo lhe escapa, pois a vida é a substancialidade como tal, o puro engendrar e dissolver de

\footnotetext{
${ }^{107}$ HEGEL, 1970 3, 142.

${ }^{108}$ HEGEL, 1970 3, 142.

${ }^{109}$ HEGEL, 1970 3, 140-141.

${ }^{110}$ McDOWELL, 2009, 164.
} 
diferenças, justamente o elemento com o qual a consciência-de-si não pode se confundir sem perder sua pretensão a ser sujeito. $O$ "objeto da consciência-de-si é também independente nessa negatividade de si mesmo e assim é, para si mesmo, gênero, universal fluidez na peculiaridade de sua distinção: é uma consciência-de-si viva"111. A pluralidade de autoconsciências fica antecipada pelos "limites" de autocertificação delimitados pela emergência da consciência-de-si a partir da substância vital: a alteridade a ser permanentemente aniquilada e, por conseguinte, incontornável. "Isso combina com a sugestão que estou fazendo de que apenas um único ser biológico individual está em jogo. A descrição da luta de vida e morte funciona como uma descrição alegórica da tentativa, da parte de uma autoconsciência simples, de afirmar sua independência, repudiando qualquer dependência de seu "modo objetivo", o qual é a vida que chegou a se estabelecer para a alteridade do mundo, cujo cenário é a vida."112

Gostaria, então, para finalizar, de recordar alguns pontos centrais da interpretação proposta por McDowell, interpretação que gira em torno da ideia de uma mediação originária entre consciência pura e consciência empírica. "Eu sustentei que 'senhorio e escravidão' descreve uma falha e, em seguida, um sucesso temporário em integrar, nos limites de um indivíduo singular, uma consciência tencionando afirmar-se a si mesma como espontaneamente aperceptiva, e uma consciência que é concebida como imersa na vida do mundo. Esta imersão na vida é, a princípio, concebida principalmente como um assunto de cognição teorética, na linha da experiência da mera consciência. Mas com o sucesso temporário, o qual se dirige ao encontro de si mesmo na atividade formativa própria, imersão na vida se torna centralmente um assunto prático" ${ }^{113}$.

\section{Referências}

ALLISON, H. Kant's Transcendental Idealism. An Interpretation and Defense. Yale University Press, 2004.

BRANDOM, R. Making It Explicit. Cambridge: Harvard University Press, 1994.

. Tales of the Mighty Dead: Historical Essays in the Metaphysics of Intentionality.

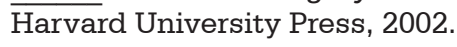

. "Hegel e Filosofia Analítica". In: Veritas, 56(1) (2011), p. 78-94.

HABERMAS, J. Verdade e Justificação: ensaios filosóficos. São Paulo: Loyola, 2004. HEGEL, G. W. F. Werke in 20 Bände. Frankfurt am Main: Suhrkamp, 1970.

\footnotetext{
${ }^{111}$ HEGEL, 1970 3, 143.

112 McDOWELL, 2009, 161.

${ }^{113}$ McDOWELL, 2009, 164.
} 
HEGEL, G. W. F. Jenaer Systementwürfe I. Hamburg: Felix Meiner, 1986.

HONNETH, A. Leiden an Unbestimmtheit. Berlin: Reclam, 2001.

HUME, D. Hume: An enquiry concerning human understanding, and other writings (Cambridge Texts in the History of Philosophy). Cambridge: Cambridge University Press, 2007.

KANT, I. Kants Werke - Akademie Textausgabe. Berlin: Walter de Gruyter, 1968.

LAFONT, C. The Linguistic Turn in Hermeneutic Philosophy. The MIT Press: Cambridge, 1999.

McDOWELL, J. Having the World in View: Essays on Kant, Hegel and Sellars. Cambridge: Harvard University Press, 2009.

. Mind and World. Cambridge: Harvard University Press, 1996.

NUZZO, A. Hegel and the Analytic Tradition. Continuum: New York, 2010.

OLIVEIRA, M. A. A reviravolta lingüístico-pragmática na filosofia contemporânea. São Paulo: Vozes, 2001.

PINKARD, T. Hegel's Phenomenology. The Sociality of Reason. Cambridge: Cambridge University Press, 1996.

PIPPIN, R. Hegel's Practical Philosophy: Rational Agency as Ethical Life. Cambridge: Cambridge University Press, 1989.

RAJCHMAN, J. Post-Analytic Philosophy. Columbia University Press: New York, 1985.

REDDING, P. Analytic Philosophy and the Return of Hegelian Thought. Cambridge University Press: New York, 2007.

. "The Analytic Neo-Hegelianism of John McDowell and Robert Brandom". In: HOULGATE \& BAUR. A Companion to Hegel. Wiley-Blackwell, 2011.

ROCKMORE, T. Hegel, Idealism, and Analytic Philosophy. Yale University Press: New York, 2005.

SELLARS, W. Empiricism and the Philosophy of Mind. Cambridge: Harvard University Press, 1997.

VERNON, J. Hegel's Philosophy of Language. Continuum: New York, 2007.

WITTGENSTEIN, L. Werkausgabe in 8 Bänden. Frankfurt: Suhrkamp, 1984.

\section{Endereço postal:}

Programa de Pós-Graduação em Filosofia

Universidade de Brasília - IH/FIL

Campus Universitário Darcy Ribeiro

Brasília, DF, Brasil

Data de recebimento: 20/06/2015

Data de aceite: 23/02/2016 